\title{
Nutrient Composition of Cereals-based Complementary Flour and its Nutritional Adequacy in Infants Nutrition
}

\author{
Nyabasi Makori ${ }^{1}$, Neema Kassim ${ }^{1}$, Joyce Kinabo ${ }^{2} \&$ Athanasia Matemu \\ ${ }^{1}$ Department of Food Biotechnology and Nutritional Sciences, School of Life Sciences and Bioengineering, \\ Nelson Mandela African Institution of Science and Technology, P. O. Box 447, Arusha, Tanzania \\ ${ }^{2}$ Department of Food Technology, Nutrition and Consumer Sciences and Technology, Sokoine University of \\ Agriculture, P. O. Box 3006. Morogoro, Tanzania \\ Correspondence: Athanasia Matemu, Department of Food Biotechnology and Nutritional Sciences, School of \\ Life Sciences and Bioengineering, Nelson Mandela African Institution of Science and Technology, P. O. Box 447, \\ Arusha-Tanzania. Tel.: 255-787-587-249. E-mail: athanasia.matemu@nmist.ac.tz
}

Received: September 2, 2017

Accepted: October 7, $2017 \quad$ Online Published: October 20, 2017

doi:10.5539/jfr.v6n6p45

URL: https://doi.org/10.5539/jfr.v6n6p45

\begin{abstract}
Evaluation of the quality of complementary flour and its nutritional adequacy in relation to infant's nutritional requirements was done to four different types of complementary flour (composite cereals with groundnuts, maize, millet and sorghum). The collected samples were analysed for determination of macronutrient, micronutrients and phytate content. The mean protein content in all types of complementary flour was $7.30 \pm 2.52 \mathrm{~g} / 100 \mathrm{~g}$. A significant difference in protein content between composite cereals $(p \leq 0.001)$ and other types of cereals-based foods was observed. Fat and iron content were found to be inadequate in all types of complementary flours. Phytate content ranged from $59.47-1176.8 \mathrm{mg} / 100 \mathrm{~g}$, the highest content was observed in sorghum. On the other hand, the mean iron and zinc content in all types of complementary flour was $5.25 \pm 1.35 \mathrm{mg} / 100 \mathrm{~g}$ and $2.99 \pm 1.36 \mathrm{mg} / 100 \mathrm{~g}$ respectively. The molar ratios of phytate:iron and phytate:zinc were at a level that would tend to inhibit bioavailability of iron and zinc in $97 \%$ and $45 \%$ of analysed samples respectively. An association between anaemia and phytate:iron molar ratio $(\mathrm{AOR}=4.2,95 \%, 1.2-6.9)$ was observed. The quality and adequacy of nutrients in cereal-based complementary flour has shown to be inadequate and likely to be compromised by the presence of phytate.
\end{abstract}

Keywords: complementary flour, proximate composition, nutrient requirement, protein, phytate, anaemia, child growth

\section{Introduction}

In developing countries, malnutrition is still a serious health problem affecting infants and young children (Ahmed, Hossain, \& Sanin, 2013; Black et al., 2013; Steiber et al., 2015). Globally and in sub Saharan Africa, 26\% and $40 \%$, of children below five years of age are stunted (UNICEF, 2013). In Tanzania, 34.4\% of children below five years are stunted and $13.7 \%$ are underweight (NBS, 2015). Though causes of malnutrition are diverse and interrelated, inadequate dietary intake during the complementary feeding period is considered to be major contributing factor (UNICEF, 2013). In most cases, cereals and legumes constitute a major portion in formulation of complementary foods, therefore it might be difficult to attain nutritional adequacy for children due to dietary related factors (Okomo et al., 2016). Nutritional deficiency, diseases and disability are considered to be a risk factor of inadequate dietary intake (Kumssa et al., 2015; Muthayya et al., 2013).

Nutrition in early life has the greatest influence on child growth, development and survival (Michaelsen, 2015; Skau et al., 2014). Following six months of exclusive breast feeding, appropriate and adequate nutritious complementary food should be introduced. The nutrient content of complementary foods should be adequate and diverse enough to meet the child's nutritional needs. Infants and young children are vulnerable to inadequate nutrient intake during the period of complementary feeding (6 -23 months), the needs of nutrients during this period is very high to support the high rate of growth while the supply is insufficient to meet the demand (Michaelsen, 2015). The first two years in life provides an opportunity for the child to achieve maximum growth potential but at the same time it is a critical period for growth faltering if the nutritional needs are not attained (Dewey, 2013). Proper physical, cognitive and intellectual development is attained by adequate nutrition in 
childhood (Onoja et al., 2014; Sudfeld et al., 2015). Therefore, in order to meet nutrient requirements, the complementary foods need to contain all essential nutrients such as carbohydrates, protein, fat, vitamins and minerals appropriate to facilitate optimal growth and development.

Lack of dietary diversity and dependence on plant-based complementary foods are some of the key factors that limit the quality of complementary diet in terms of nutrient content and bioavailability (Gatahun et al., 2015; Shiriki et al., 2015). Furthermore, the presence of anti-nutritional factors such as phytate, limits nutrients bioavailability as it chelates divalent cations ( $\mathrm{Fe}, \mathrm{Zn}, \mathrm{Ca}$ ). Phytate in cereals tend to affects the bioavailability of minerals and reduce the chances of being absorbed in the body (Platel \& Srinivasan, 2015). More than $80 \%$ of children (6 - 23 months) in Africa do not attain a minimum acceptable diet during complementary feeding period, especially in areas where there is a problem of food scarcity (de Onis \& Branca, 2016). Relying on cereal-based complimentary foods might limit micronutrient bioavailability and attainment of nutrients adequacy which may collectively have a negative effect on nutritional status of a child during the critical period of growth. In this context, complementary flour are basically cereal-based used to prepare porridge and other traditional complementary food. In low resource settings, they are stirred up solely with water and boiled as plain porridge or added with minimum ingredients such as milk, lemon juice, cooking oil, margarine or butter. Therefore, the aim of this study was to evaluate the nutritional quality of cereal-based complementary flour used to prepare complimentary food for infants and young children (6 - 23 months) and to assess its nutrient adequacy in relation to infant's/child's nutritional requirements, in order to advocate for improvement.

\section{Materials and Methods}

\subsection{Study Area, Design and Sampling Procedure}

Dodoma region was purposively selected for being a study area due to the fact that it was having high prevalence of stunting (56\%) in children of under five years of age (NBS, 2011). Out of seven districts in this region, Dodoma Municipality and Chamwino District were randomly selected to be the study area. Three wards (Chigongwe, Makole and Mahoma Makulu) from Dodoma Municipality and two wards (Ikowa and Mlowa) from Chamwino district were also randomly selected. Five villages were recruited in this study, whereby in each ward one village was randomly selected. A list of all households that were having children of age between 6 and 23 months was obtained from the respective village offices, a systematic randomly sampling technique was used to select all households recruited in this study followed the criteria of having a child who is receiving a complementary food. A cross-sectional study involved a total of 100 children (48\% male and $52 \%$ female) who were between the age ranges of $6-23$ months. A total of 100 complementary flour samples used for preparation of complementary food were collected from households. Four different types of cereals-based complementary flour were collected from the households [composite cereals with groundnuts $(\mathrm{n}=51)$, maize $(\mathrm{n}=22)$, millet $(\mathrm{n}$ $=18)$ and sorghum $(\mathrm{n}=9)]$. From each selected household, approximately $100-150 \mathrm{~g}$ of locally made complementary flour was collected and kept at room temperature. The collected samples were then taken to the laboratory, stored at $4{ }^{\circ} \mathrm{C}$ for further analysis. Infants were assessed for haemoglobin status by using Hemo Control Hemoglobin and Hematocrit Analyzer (EFK Diagnostic, GmbH Germany), association between phytate intake and haemoglobin level was determined.

\subsection{Dietary Pattern}

Repeated $24 \mathrm{~h}$ dietary recall method was used to capture detailed information provided by a mother/care-giver for all food items and drinks consumed by a child for the past $24 \mathrm{~h}$ in two non-consecutive visit. Amount of food reported to be consumed by infants and young children in $24 \mathrm{~h}$ dietary recall was estimated by using household utensils such as cups, bowls and spoons. The consumption rate of a child was calculated by considering weight of the food per serving and meal frequency per day. Nutrient adequacy of complementary foods was calculated based on the amount of food consumed per day. Calculated nutrient intake was compared with Recommended Dietary Intake (RDI) of respective age category.

\subsection{Proximate Composition Analysis}

Proximate composition of different types samples were analysed for protein, moisture content, crude fat, ash, fiber and carbohydrates. Standard procedures as described by the Association of Official Analytical Chemists (AOAC, 2005) were used to determine the nutrient composition of the samples. Protein content was determined by Kjeldhal method (method no. 960.52), moisture content was determined by hot air oven (method no. 925.10), ash content was determined by using muffle furnace (method no. 923.03), crude fat was determined by method no. 2003.05 and fiber content was determined by (method no. 962.09). Carbohydrate was determined by subtraction of percentage of protein, fat, moisture, ash and fiber from 100. Results of analysis of proximate composition were expressed per $100 \mathrm{~g}$ of the dry weight matter. 


\subsection{Determination of Phytate}

Phytate content in samples was determined using a method described by Holt's (1955) with some modifications (Davies \& Reid, 1979). Briefly, $0.25 \mathrm{~g}$ of sample was extracted with $10 \mathrm{~mL}$ of $0.5 \mathrm{M}$ nitric acid $\left(\mathrm{HNO}_{3}\right)(\mathrm{Ajax}$ Finechem, India) by continuous shaking placed over night in a Shaker (ThermoScientific, USA). The extract was filtered through Whatman filter paper no. 3 (Sigma-Aldrich, South Africa). An aliquot $(1.0 \mathrm{~mL})$ of the filtrate was then diluted with distilled water to a final volume of $1.4 \mathrm{~mL}$, then $1 \mathrm{~mL}$ of a ferric ammonium sulphate solution $\left(\mathrm{NH}_{4} \mathrm{Fe}\left(\mathrm{SO}_{4}\right)_{2}\right)$ was added and well mixed. The test tubes contained the mixture was immersed into water bath (Memmert, Germany) at $100^{\circ} \mathrm{C}$ for $20 \mathrm{~min}$, then cooled at a room temperature. Five millilitres of amyl alcohol $\left(\mathrm{C}_{5} \mathrm{H}_{11} \mathrm{OH}\right)$ (Sigma-Aldrich, South Africa) and $0.1 \mathrm{~mL}$ of ammonium thiocyanate $\left(\mathrm{NH}_{4} \mathrm{SCN}\right)$ (Abron Chemicals, India) solution were added and immediately mixed by inversion and shaking and then centrifuged at $3000 \mathrm{rpm}$ for $5 \mathrm{~min}$. The intensity of colour in the amyl layer was determined at $465 \mathrm{~nm}$ using Spectrophotometer (SQ-2800 Single Beam, UNICO) against an amyl alcohol 'blank' exactly 15 min after addition of NH4CNS. Phytate content in a sample was expressed per $\mathrm{mg} / 100 \mathrm{~g}$ of dry weight matter.

\subsection{Determination of Minerals (Zinc and Iron)}

Zinc and iron contents were determined by a method described by Association of Official Analytical Chemists AOAC, (2000). A gram of homogenized sample on the crucibles was placed in Muffle furnace at $550{ }^{\circ} \mathrm{C}$ for $4 \mathrm{~h}$. Appearance of grey white ash indicated complete oxidation of all organic matter in the sample. The crucibles containing ashes were left to cool at room temperature $\left(26^{\circ} \mathrm{C}\right.$ ), then $10 \mathrm{~mL}$ of $0.1 \mathrm{~N} \mathrm{HCl}$ (LaborChemie, Germany) was added in order to dissolve ashes. The solution was filtered using Whatman filter paper no. 1 (Sigma-Aldrich, South Africa). The filtrate was used for iron and zinc quantification using Atomic Absorption Spectrophotometer (ThermoScientific, USA) at wavelength of $248.3 \mathrm{~nm}$ and $213.9 \mathrm{~nm}$ respectively.

\subsection{Determination of Molar Ratio of Phytate: Mineral}

Mole of phytate, zinc and iron was calculated by dividing the weight of phytate and minerals (zinc and iron) with its molecular weight $(660 \mathrm{~g} / \mathrm{mol}$ for phytate, $65 \mathrm{~g} / \mathrm{mol}$ for zinc and $56 \mathrm{~g} / \mathrm{mol}$ for iron) (Mahfuz et al., 2016; Norhaizan \& Norfaizadatul, 2009). The molar ratio was obtained by dividing the mole of phytate with the mole of zinc as well as mole of iron. Phytate: minerals ratio was used to estimate the bioavailability of minerals. The recommended limits of phytate: iron and phytate:zinc were 1 and 15 respectively (Mahfuz et al., 2016).

\subsection{Determination of Hemoglobin Level}

The hemoglobin concentration of infants (6 - 23 months) was determined using Hemo Control Hemoglobin and Hematocrit Analyzer (EFK Diagnostics, GmbH Germany). The middle finger at the top side was cleaned (using a cotton wool) and then pricked using sterile disposable lancet. Drops of blood was filled at the centre of cuvette, immediately was placed into a holder and pushed to its position for reading. Hemoglobin concentration was expressed as g/dL. Categorization of hemoglobin level was done as per WHO reference standards (WHO, 2011), as presented in the Table 1.

Table 1. Haemoglobin cut off points to define anaemia

\begin{tabular}{ll}
\hline Category & Haemoglobin $(\mathbf{g} / \mathbf{d l})$ cut off point \\
\hline Non anaemia & 11.0 or above \\
Mild anaemia & $10.0-10.9$ \\
Moderate anaemia & $7.0-9.9$ \\
Severe anaemia & Below 7.0 \\
\hline
\end{tabular}

\subsection{Ethical Clearance}

Ethical approval for conducting the present study was obtained from the National Health Research Ethics Sub-Committee (NatHREC) of the National Institute of Medical Research (NIMR) of Tanzania, reference number NIMR/HQ/R.8a/Vol.IX/1973. Parent/care taker of each individual child signed an informed consent. Confidentiality was observed throughout the study.

\subsection{Statistical Analysis}

Data were coded and entered into an Epidata version 3.1, then exported to Statistical Package for Social Studies (SPSS) for windows software (IBM version 21) for analysis. Difference between groups was compared using Chi-square statistical test, the strength of association were assessed using Crude Odds Ratio (COR) and Adjusted 
Odds Ratio (AOR). Differences were considered statistically significant if $p \leq 0.05$. One way ANOVA was used to compare means between types of complementary four, significant difference were established when $p \leq 0.05$.

\section{Results}

\subsection{Dietary Pattern}

Dietary pattern of studied population was cereal-based products where by all infants and young children (6 - 23 months) were introduced to cereal-based complementary foods. The mean consumption rate of complementary foods per child was $145 \mathrm{~g} /$ day, the minimum value was $91 \mathrm{~g} /$ day and maximum was $293 \mathrm{~g} /$ day. The composite complementary flours were formulated by using different types of cereals ranging from 2-7 types (i.e., maize, millet, sorghum, rice, finger millet, wheat, beans) groundnuts was the main ingredient. The consumption of dairy products, fruits, vegetables and other animal foods source were consumed by $11 \%, 7.1 \%, 57.9 \%$ and $18 \%$ of infants respectively. The mean carbohydrate content of composite cereals-based complementary flour provided $2.8 \mathrm{kcal} / \mathrm{g}(2.3-3.19 \mathrm{kcal} / \mathrm{g})$. Based on the consumption data, the mean protein intake among infants was $8.43 \pm$ $0.31 \mathrm{~g}$ per day. The RDI of fat for infants and young children was not attained by all types of complementary foods fed to infants. Fat content was able to supply $19 \%$ of energy required by infants. Iron intake was inadequate whereby only $6 \%(\mathrm{n}=100)$ of infants $(12-24$ months $)$ met the RDI. The mean zinc intake among infants was $2.99 \pm 1.36 \mathrm{~g} / \mathrm{day}$, where by $75 \%(\mathrm{n}=100)$ of infants met the RDI of zinc.

\subsection{Proximate Composition}

Results of proximate composition of four different types of complementary flour are presented in Table 2 . The protein content of composite cereals complementary flour was higher $7.30 \pm 2.52 \mathrm{~g} / 100 \mathrm{~g}$ compared to maize, millet and sorghum. A significance difference $(p \leq 0.001)$ in protein content between composite cereals and other types of sample was observed. The mean difference of protein content in different types of complementary flour is presented in Table 3. The protein content of cereals-based foods ranged from $1.17-11.17 \mathrm{~g} / 100 \mathrm{~g}$ of dry weight matter. Fat content ranged from $0.61-11.19 \mathrm{~g} / 100 \mathrm{~g}$ and composite cereals had the highest fat content. Insignificant difference $(p=0.51)$ in fat content between composite cereals and other types of samples was observed. On the other hand, the fiber content ranged from $1.03-13.27 \mathrm{~g} / 100 \mathrm{~g}$, whereas the highest fiber content was found in maize. The minimum and maximum carbohydrate content was 59.68 and $79.97 \mathrm{~g} / 100 \mathrm{~g}$ respectively, with maize showed slightly higher value as opposed to composite cereals. Furthermore, the moisture content of complementary flour was found to be within acceptable range $7.01-14.01 \mathrm{~g} / 100 \mathrm{~g}$ (McLean, Cogswell, Egli, Wojdyla, \& de Benoist, 2009). The ash content was found in a range of $0.23-3.57 \mathrm{~g} / 100 \mathrm{~g}$.

Table 2. Proximate composition $[\mathrm{g} / 100 \mathrm{~g}]$ of different types of complementary flour

\begin{tabular}{llllllll}
\hline Type of CF & $\mathbf{n}$ & Protein & Fat & Fiber & Ash & Moisture & CHO \\
\hline Composite cereals & 51 & $8.70 \pm 2.24$ & $4.7 \pm 2.12$ & $3.6 \pm 2.09$ & $1.78 \pm 0.65$ & $8.54 \pm 0.90$ & $70.54 \pm 3.27$ \\
Maize & 22 & $7.09 \pm 2.05$ & $3.34 \pm 2.06$ & $5.09 \pm 1.50$ & $1.87 \pm 0.68$ & $9.6 \pm 1.98$ & $74.01 \pm 3.74$ \\
Millet & 18 & $5.87 \pm 1.66$ & $3.7 \pm 2.36$ & $3.69 \pm 0.88$ & $1.5 \pm 0.58$ & $9.11 \pm 1.02$ & $72.39 \pm 4.49$ \\
Sorghum & 9 & $6.97 \pm 2.05$ & $3.67 \pm 1.88$ & $3.78 \pm 0.51$ & $1.9 \pm 0.55$ & $8.7 \pm 1.30$ & $73.40 \pm 2.96$ \\
Over all & 100 & $7.30 \pm 2.52$ & $4.15 \pm 2.19$ & $4.0 \pm 2.30$ & $1.78 \pm 0.64$ & $8.92 \pm 1.33$ & $71.83 \pm 3.80$ \\
\hline
\end{tabular}

Values are expressed as mean \pm standard deviation

Table 3. The mean difference of protein content among different types of samples and its significance

\begin{tabular}{|c|c|c|c|}
\hline \multicolumn{2}{|c|}{ Type of complementary flour (b) } & \multirow{2}{*}{$\frac{\text { Mean Difference }(\mathrm{a}-\mathrm{b})}{3.10158^{*}}$} & \multirow{2}{*}{$\frac{\text { Sig. }}{0.000}$} \\
\hline Composite cereals & Maize & & \\
\hline & Millet & $2.82627 *$ & 0.000 \\
\hline & Sorghum & $2.28072 *$ & 0.003 \\
\hline \multirow[t]{3}{*}{ Maize } & Composite cereals & -3.10158 & 0.000 \\
\hline & Millet & -0.27530 & 0.681 \\
\hline & Sorghum & -0.82086 & 0.327 \\
\hline \multirow[t]{3}{*}{ Millet } & Composite cereals & -2.82627 & 0.000 \\
\hline & Maize & 0.27530 & 0.681 \\
\hline & Sorghum & -0.54556 & 0.527 \\
\hline \multirow[t]{3}{*}{ Sorghum } & Composite cereals & -2.28072 & 0.003 \\
\hline & Maize & 0.82086 & 0.327 \\
\hline & Millet & 0.54556 & 0.527 \\
\hline
\end{tabular}

* The mean difference is significant at 0.05 , Sig: Significance 


\subsection{Minerals and Phytate}

The results of iron and zinc are presented in Table 4. Sorghum showed the highest iron content of $8.37 \mathrm{mg} / 100 \mathrm{~g}$ with the lowest value of $0.17 \mathrm{mg} / 100 \mathrm{~g}$ found in millet. A non-significance difference in iron content between types of samples $(p=0.233)$ was observed. Highest zinc content was found in composite cereals (5.92) and the lowest value was found in millet $0.50 \mathrm{mg} / 100 \mathrm{~g}$. A significance difference in zinc content between composite cereals and maize $(p=0.010)$, sorghum and maize $(p=0.044)$ and sorghum and millet $(p=0.033)$ were observed. Phytate content in different types of complementary flour (composite cereals, maize, millet and sorghum) is presented in Table 5. The highest phytate content of $1176.8 \mathrm{mg}$ was found in sorghum whereas the composite cereals exhibited the minimum value of $59.47 \mathrm{mg}$.

Table 4 . The mean minerals content $[\mathrm{mg} / 100 \mathrm{~g}]$ in different types of complementary flour

\begin{tabular}{llllll}
\hline Type of CF & n & Iron & Range & Zinc & Range \\
\hline Composite cereal & 51 & $5.14 \pm 1.23$ & $3.17-8.36$ & $3.34 \pm 1.31$ & $0.63-5.92$ \\
Maize & 22 & $5.3 \pm 1.77$ & $0.17-8.19$ & $2.4 \pm 1.35$ & $0.63-5.63$ \\
Millet & 18 & $5.02 \pm 0.94$ & $3.37-6.89$ & $2.3 \pm 1.2$ & $0.50-4.84$ \\
Sorghum & 9 & $6.06 \pm 1.45$ & $4.19-8.37$ & $3.5 \pm 1.05$ & $1.37-5.22$ \\
Over all & 100 & $5.25 \pm 1.35$ & $0.17-8.37$ & $2.99 \pm 1.36$ & $0.50-5.92$ \\
\hline
\end{tabular}

Values are expressed as mean \pm standard deviation

Table 5. Mean phytate content $[\mathrm{mg} / 100 \mathrm{~g}]$ and phytates:minerals molar ratio in different types of samples

\begin{tabular}{llllll}
\hline Type of CF & $\mathbf{n}$ & Phytate & Range & $\begin{array}{l}\text { Phytates:Iron } \\
\text { molar ratio }\end{array}$ & $\begin{array}{l}\text { Phytates:Zinc } \\
\text { molar ration }\end{array}$ \\
\hline Composite cereal & 51 & $246.19 \pm 11.66$ & $59.47-821.03$ & $4.21 \pm 2.97$ & $10.13 \pm 15.65$ \\
Maize & 22 & $211.57 \pm 6.82$ & $59.50-320.95$ & $6.4 \pm 14.05$ & $12.2 \pm 9.25$ \\
Millet & 18 & $306.34 \pm 15.67$ & $126.87-716.49$ & $5.6 \pm 4.00$ & $18.20 \pm 0.4$ \\
Sorghum & 9 & $387.42 \pm 3.52$ & $163.27-1176.8$ & $3.77 \pm 1.60$ & $8.20 \pm 4.42$ \\
Over all & 100 & $262.09 \pm 18.18$ & $59.47-1176.80$ & $4.93 \pm 7.10$ & $11.87 \pm 13.87$ \\
\hline
\end{tabular}

Values are expressed as mean \pm standard deviation

\subsection{Minerals Bioavailability}

The phytate:iron and phytate:zinc molar ratios are presented in Table 5. Three percent of cereals-based samples had molar ratios of phytates:iron below 1 which is within acceptable range whilst $97 \%(n=100)$ of samples were above 1 indicating that the absorption of iron might be significantly inhibited by the presence of phytate. The highest phytate:iron molar ratio was found in maize 69.22 followed by millet 18.04 , composite cereals (16.13) and sorghum (6.99) respectively. The molar ratio of phytate:zinc, in $55 \%(\mathrm{n}=100)$ of the samples was below the cut-off point $(<15)$ and $45 \%(\mathrm{n}=100)$ was above the level which might limit the absorption of zinc. The highest level of 109.10 was found in composite cereals as opposed to millet with the lowest level of 57.04. The overall mean of phytate:zinc molar ratio was $11.87 \pm 13.87$.

\subsection{Haemoglobin Level}

The prevalence of anemia among children was $69 \%$ which is considered to be severe and of public health concern according to WHO standards (McLean et al., 2009). Based on hemoglobin levels, 4.6\% $(\mathrm{n}=18)$ of children were severely anemic, $36.3 \%(\mathrm{n}=143)$ and $28.2 \%(\mathrm{n}=111)$ had moderate and mild anemia respectively. Significant association between anemia and phytates:iron molar ratio ( $\mathrm{AOR}=4.2,95 \%, 1.2-6.9)$ was observed.

\section{Discussion}

In developing countries cereals are used as the main ingredients in traditional complementary foods for children. They are known to provide reasonable amount of protein, carbohydrate and vitamins (Oghbaei, Prakash, \& Yildiz, 2016). Analysis of complementary flour in this study indicated that protein content in composite cereals was higher compared to other types of foods. A significant difference $(p \leq 0.001)$ in protein composition between composite cereals and other types might be due to inclusion of groundnuts which boosted the overall protein content. Variation on the addition of groundnuts during formulation was observed among households, varying from 0.5 to $2.5 \mathrm{Kgs}$ depending on the final weight of complementary flour intended to be formulated. Groundnuts provide reasonable amount of protein and other essential nutrients (Mandal, 2016). Despite composite cereals having higher protein content, it did not meet infant's RDI of protein. The proportion of 
protein in all other types of samples were inadequate, observed to be below RDI for infants which is $16 \mathrm{~g}$ per day (Shiriki et al., 2015). The actual protein intake was slightly lower than RDI, indicating the intake of protein was inadequate. This might be due to lack of dietary diversity, less consumption of animal food sources and dependence on cereals-based complementary foods as the main source of protein. The consumption of the dairy product and animal food source were noted to be less consumed by $11 \%$ and $18 \%$ respectively. Similarly, Anigo et al (2009) reported very low level of protein $(5.23 \pm 0.03 \mathrm{~g} / 100 \mathrm{~g})$ in maize based foods which did not meet the RDI for infants (Anigo el al., 2009). The adequate intake of protein is essential for meeting the growing demand of children especially during this critical stage of growth. Growing children require a constant supply of protein for growth, building up new tissues and body maintenance (Michaelsen \& Greer, 2014). Inadequate intake of protein for a long time may lead to protein deficiency which may interfere the growth process. Therefore, ensuring the adequate supply of protein during infancy and childhood will facilitate proper growth. However, enrichment of protein content in cereals-based complementary food with protein dense foods have been reported by Steve and Babatunde, (2013).

Energy from the diet is recommended to be adequate to meet the physiological requirement of the body. The energy requirement is expressed as energy intake from the food that will balance energy expenditure (Butte, 2005). Carbohydrate serves as a primary source of energy in the body. Complementary flours were characterized by having adequate carbohydrate content, according to FAO/WHO (1991) (FAO/WHO, 1991). A $100 \mathrm{~g}$ of flour is required to provide $64 \mathrm{~g}$ of carbohydrate, which is considered to be sufficient to meet the energy requirement. Furthermore, WHO recommended energy density in complementary food should be in a range of $0.8-1.0 \mathrm{kcal} / \mathrm{g}$ (WHO, 2009). The present study found that the mean carbohydrate value $(71.8 \pm 3.80 \mathrm{~g} / 100 \mathrm{~g})$ was above the reference point, indicating the adequacy on providing energy that is needed by the body. Additionally, the minimum and maximum carbohydrate content was able to provide $2.3 \mathrm{kcal} / \mathrm{g}$ and $3.19 \mathrm{kcal} / \mathrm{g}$ respectively, which was above WHO recommendation signifying the provisional of optimal energy to meet energy needs of infants of the age group of 6 - 23 months. Nevertheless, attainment of daily recommended energy intake depends on the frequency of the meal, amount of the food consumed, and energy density of the food (Adimasu, Lelisa, \& Geleta, 2016). Therefore, adequate intake of energy promotes optimal growth and development.

Fat content was observed to be very low due to the fact that cereals contain little fat. Dietary fat is essential for the supply of energy in the body, facilitate absorption of fat soluble vitamins and provide essential fatty acids that are required for normal brain development (Aranceta \& Pérez-Rodrigo, 2012). All types of complementary flour was not able to provide the RDI of fat which is $30 \mathrm{~g}$ per day for infants of the age group of $7-12$ months (USDA, 2009). From this study, fat content observed to provide only $19 \%$ of energy whereas dietary fat is required to contribute 35\% of total energy required by the body (Adimasu et al., 2016; Lutter \& Dewey, 2003). The results suggest that inadequate fat intake might be due to consumption of cereal-based food which is known to contain little fat. Friel et al (2010) found fat intake of $5.9 \mathrm{~g} / \mathrm{day}$ from complementary foods which did not meet recommended level (Friel et al., 2010). The limited supply of dietary fat to infant prevent the body from receiving adequate energy needed for growth and other body function hence adversely affect the growth pattern.

On the other hand, fiber content observed in this study (Table 1) was slightly higher than values reported by Udensi et al (2012) (Udensi, Odom, \& Ihemanma, 2012). The mean fiber content in maize based complementary flour $(5.09 \pm 1.50 \mathrm{~g} / 100 \mathrm{~g})$ was reported to be similar with the recommended value of $5 \mathrm{~g} / 100 \mathrm{~g}$ (Gibson et al., 2010; Onomi et al., 2004). The practice of using whole (unrefined) cereals in formulation of complementary flour contributed to the increase in fiber content, especially in maize-based food. The physiological role of fiber is to maintain an internal distension for peristaltic movement of the intestine (Alexy, Kersting, \& Sichert-Hellert, 2006). Infant diet with high fiber content is not advisable as it tends to reduce nutrient digestibility as well as increase malabsorption of micronutrient, under this condition growth retardation may occur (Edwards \& Parrett, 2003). Therefore, it is important to note that fiber content of infant's diets should not exceed the recommended level.

Iron and zinc are important micronutrients required by infants and young children to facilitate optimal growth. Low iron content to meet the daily nutritional requirement for children belonging to the age group of $7-12$ months was found in analysed cereal-based foods. Infants in this age group require $11 \mathrm{mg}$ per day (RDI) (Domellöf et al., 2014). None of the samples was able to meet the daily iron needs of this group. Iron requirement tends to decline as the age of a child increase. The RDI of age group 13 - 24 months is $7 \mathrm{mg}$ per day (Beard, 2008) thus only 6\% of infants for this age group their iron requirement was met. Inadequate intake of iron may interfere with the biochemical function of the body including impairment of cognitive development (Beard, 2008). Zinc content was adequate in 55\% ( $\mathrm{n}=100)$ of collected samples, were able to meet the requirement of infants (7 - 24 months) which is $3 \mathrm{mg}$ per day (USDA, 2009). Regardless of higher zinc content 
in foods, their availability in the body might be interfered by the presence of phytate which tend to inhibit the bioavailability of minerals in the body (Lazarte et al., 2015).

Cereals and legumes are naturally containing anti-nutritional factors including phytate which limits the accessibility of minerals (Abdel-Gawad et al., 2013). The phytate content in all samples was found to exceed the tolerable level for human consumption. According to Onomi et al (2004), the tolerable level for phytate is 25 $\mathrm{mg} / 100 \mathrm{~g}$. Nonetheless, below this level the micronutrient losses are minimized (Maseta et al., 2016). The range of phytate found in this study was $59.47-1176.80 \mathrm{~g} / 100 \mathrm{~g}$, Gibson et al (2010) reported phytate content of 600 $\mathrm{mg} / 100 \mathrm{~g}$ in unrefined cereals and legumes-based complementary foods. Since most of cereal-based products are naturally known to contain phytate, this further supports the fact that minerals bioavailability can be impeded. Attainment of adequate bioavailable minerals in the body is affected by the presence of phytate in the diet which tends to form complex compounds which are not absorbed in the gastro intestinal tract (Kana Sop et al., 2012; Roohani et al., 2013). Phytate compromises the bioavailability of minerals which are very important for growth promotion and development of a child (Lazarte et al., 2015). The inhibitory effect of phytate on mineral bioavailability however depends on the molar ratio of phytate:minerals. As the molar ratios increase, also the inhibitory effect of minerals absorption increases. From the study, the molar ratio of phytate:iron and phytate:zinc were all above the tolerable limit by $97 \%$ and $45 \%$ of analyzed samples respectively. The intake of phytate through foods increased the odds of infants being anemic by 4.2 times higher to children who were using cereals based-complementary foods $(p=0.005)$. Inadequate supply of iron due to dietary related factors may lead to iron deficiency which is the primary cause of anemia (Rao \& Parikh, 2015). Similarly, this study reported that, the prevalence of anaemia was $69 \%$, implying low hemoglobin level which might be contributed by inadequate intake of iron. According to Warthn-Medina et al (2015) micronutrients needs in the first two years of child's life is very high to meet physiological requirements (Warthon-Medina et al., 2015). Micronutrients deficiency contribute to impairment of child growth, cognitive and motor development and affect immunological functioning (Rohner et al 2013; Wieser et al., 2013; Wong et al., 2014). Thus, infants should receive the most nutrient-rich foods to meet their optimal nutrient needs per each age group.

Preliminary food processing methods such as germination, soaking, milling fermentation, heat treatment have been reported to reduce phytate levels in plant-based food (Fabbri \& Crosby, 2015; Oghbaei et al., 2016). However, results from this study have shown that $87 \%$ of cereal-based food products were not subjected to preliminary food preparation methods. Additionally, only $8 \%$ of samples were refined maize flour though persistence of phytate was observed at the low level of $59.47 \mathrm{mg} / 100 \mathrm{~g}$. Henceforth, it is recommended that the use of preliminary food processing methods on cereal-based foods is important for the purpose of enhancing minerals bioavailability. Likewise, Lestienne et al (2005) reported a reduction of phytate level in cereals (millet) by $29 \%$ after soaking and $39 \%$ after soaking the dehulling. Some of the food processing methods tend to increase nutrient digestibility and bioavailability of minerals. Therefore, application of food processing method in reducing anti-nutritional factors is essential to enhance minerals bioavailability.

\section{Conclusions}

The cereal-based complementary flour were found to meet the adequacy of the nutritional requirement of children (6 - 23 months) in terms of carbohydrate, zinc and fiber as opposed to protein, fat and iron. Similarly, high levels of phytate above tolerable limits was detected which tend to compromise minerals (zinc and iron) bioavailability and therefore increases the odds of developing micronutrient deficiency. Therefore, shifting from cereal-based diets observed to be monotonous to diversified diets would increase the chances of offering diverse nutrients, by increasing the likelihood of attaining nutritional goal to infants and young children. In this case promotion of dietary diversification among mothers and care-givers to enhance the attainment of adequate nutrients is required so that infants and young children would be able to achieve the optimal growth potentials.

\section{Acknowledgments}

This study was supported by the Government of Tanzania through Nelson Mandela African Institution of Science and Technology. The authors express their appreciations for Beatus Lyimo guidance on the laboratory work.

Author Contributions: Nyabasi Makori designed the research, conducted the literature search, participated in laboratory work, data extraction and analysis, and wrote the draft of manuscript. Athanasia O. Matemu, Neema Kassim and Joyce Kinabo participated on designing of the work, provided input for the data analysis and critically reviewed and contributed to the manuscript. All authors reviewed the submitted manuscript and approved for submission in this journal. 


\section{References}

Abdel-Gawad, AS, Ramadhani, B. R., \& Oraby, R. E. A. (2013). Legume phytases: characteristics and changes in activity during germination. Nternational Journal of Agriculture Policy and Research, 1(4), 93-102. Retrieved from http://www.cabdirect.org/abstracts/20143411899.html

Adimasu, M., Lelisa, A., \& Geleta, B. (2016). Complementary Feeding: Review of Recommendations, Feeding Practices, and Adequacy of Homemade Complementary Food Preparations in Developing Countries Lessons from ethiopia. Front. Nutr, 3(3), 413389-41. https://doi.org/10.3389/fnut.2016.00041

Ahmed, T., Hossain, M., \& Sanin, K. I. (2013). Global burden of maternal and child undernutrition and micronutrient deficiencies. Annals of Nutrition and Metabolism, 61(suppl 1), 8-17. https://doi.org/10.1159/000345165

Alexy, U., Kersting, M., \& Sichert-Hellert, W. (2006). Evaluation of dietary fibre intake from infancy to adolescence against various references - results of the DONALD Study. European Journal Of Clinical Nutrition, 60(7), 909-914. https://doi.org/10.1038/sj.ejcn.1602400

Anigo, K. M., Ameh, D. a, Ibrahim, S., \& Danbauchi, S. S. (2009). Nutrient composition of commonly used complementary foods in North western Nigeria. African Journal of Biotechnology, 8(17), 4211-4216. https://doi.org/10.4314/ajb.v8i17.62358

Aranceta, J., \& Pérez-Rodrigo, C. (2012). Recommended dietary reference intakes, nutritional goals and dietary guidelines for fat and fatty acids: a systematic review. British Journal of Nutrition, 107(S2), S8-S22. https://doi.org/10.1017/S0007114512001444

Association of Official Analytical Chemists (AOAC). (2000). Determination of Lead, Cadmium, Copper, Iron and Zinc in Foods Using Atomic Spectrophotometer After Ashing. Officil Method No. 999.11.

Association of Official Analytical Chemists (AOAC). (2005). . Determination of Moisture content, Fat content, Ash content, Protein content and Fibre content in Foods using. Official Method no. 925.10, 2003.05, 923.03, 960.52 and 962.09 respectively.

Beard, J. L. (2008). Why iron deficiency is important in infant development. The Journal of Nutrition, 138(12), 2534-2536. https://doi.org/138/12/2534 [pii]

Black, R. E., Victora, C. G., Walker, S. P., Bhutta, Z. A., Christian, P., de Onis, M., ... Uauy, R. (2013). Maternal and child undernutrition and overweight in low-income and middle-income countries. The Lancet, 382(9890), 427-451. https://doi.org/10.1016/S0140-6736(13)60937-X

Butte, N. F. (2005). Energy requirements of infants. Public Health Nutrition, 8(7a), 957-967. https://doi.org/10.1079/PHN2005790

Davies, N. T., \& Reid, H. (1979). An evaluation of the phytate, zinc, copper, iron and manganese contents of, and zn availability from, soya-based textured-vegetable-protein meat-substitutes or meat-extenders. British Journal of Nutrition, 41(3), 579-89. https://doi.org/10.1079/BJN19790073

de Onis, M., \& Branca, F. (2016). Childhood stunting: A global perspective. Maternal and Child Nutrition, 12, 12-26. https://doi.org/10.1111/mcn.12231

Dewey, K. (2013). The challenge of meeting nutrient needs of infants and young children during the period of complementary feeding: an evolutionary perspective. The Journal of Nutrition, 143, 2050-2054. https://doi.org/10.39.45/jn.113.182527

Domellöf, M., Braegger, C., Campoy, C., Colomb, V., Decsi, T., Fewtrell, M., ... van Goudoever, J. (2014). Iron requirements of infants and toddlers. Journal of Pediatric Gastroenterology and Nutrition, 58(1), 119-29. https://doi.org/10.1097/MPG.0000000000000206

Edwards, C. a, \& Parrett, a M. (2003). Dietary fibre in infancy and childhood. The Proceedings of the Nutrition Society, 62, 17-23. https://doi.org/10.1079/PNS2002231

Fabbri, A. D. T., \& Crosby, G. a. (2015). A review of the impact of preparation and cooking on the nutritional quality of vegetables and legumes. International Journal of Gastronomy and Food Science, 1-10. https://doi.org/10.1016/j.ijgfs.2015.11.001

FAO/WHO. (1991). Guidelines on Formulated Supplementary Foods For Older Infants and Young Children. Joint Publication (Vol. 4).

Friel, J. K., Hanning, R. M., Isaak, C. a, Prowse, D., \& Miller, A. C. (2010). Canadian infants' nutrient intakes 
from complementary foods during the first year of life. BMC Pediatrics, 10, 43.

https://doi.org/10.1186/1471-2431-10-43

Gatahun, E. A., \& Direseling M. Abyu. (2015). Nutrition \& Food Sciences Dietary Diversity Feeding Practice and Determinants among Children Aged 6-23 Months in Kemba Woreda, Southern Ethiopia Implication for Public Health Intervention. Nutrition and Food Sciences, 13003(13), 1-9. https://doi.org/10.4172/2155-9600.1000S13003

Gibson, R. S., Bailey, K. B., Gibbs, M., \& Ferguson, E. L. (2010). A review of phytate, iron, zinc, and calcium concentrations in plant-based complementary foods used in low-income countries and implications for bioavailability. Food Nutr Bull, 31(2), S134-46. https://doi.org/doi:10.1007/s00394-006-0637-4 Suppl. S

Kana Sop, M. M., Gouado, I., Mananga, M. J., Djeukeu Asongni, W., Amvam Zollo, P. H., Oberleas, D., \& Tetanye, E. (2012). Trace elements in foods of children from Cameroon: A focus on zinc and phytate content. Journal of Trace Elements in Medicine and Biology, 26(2-3), 201-204.

https://doi.org/10.1016/j.jtemb.2012.03.018

Kumssa, D. B., Joy, E. J. M., Ander, E. L., Watts, M. J., Young, S. D., Walker, S., \& Broadley, M. R. (2015). Dietary calcium and zinc deficiency risks are decreasing but remain prevalent. Scientific Reports, 5, 1-11. https://doi.org/10.1038/srep10974

Lazarte, C. E., Carlsson, N.-G., Almgren, A., Sandberg, A.-S., \& Granfeldt, Y. (2015). Phytate, zinc, iron and calcium content of common Bolivian food, and implications for mineral bioavailability. Journal of Food Composition and Analysis, 39, 111-119. https://doi.org/10.1016/j.jfca.2014.11.015

Lestienne, I., Mouquet-Rivier, C., Icard-Vernière, C., Rochette, I., \& Trèche, S. (2005). The effects of soaking of whole, dehulled and ground millet and soybean seeds on phytate degradation and Phy/Fe and Phy/Zn molar ratios. International Journal of Food Science and Technology, 40(4), 391-399. https://doi.org/10.1111/j.1365-2621.2004.00941.x

Lutter, C. K., \& Dewey, K. G. (2003). Nutrient Composition for Fortified Complementary Foods Proposed Nutrient Composition for Fortified Complementary Foods 1. Journal of Nutrition, 133, 2962-2972.

Mahfuz, S., Hasan, A., Hassan, M., Saha, S., Islam, M., Billah, M., \& Islam, S. (2016). Dietary phytate intake inhibits the bioavailability of iron and calcium in the diets of pregnant women in rural Bangladesh: a cross-sectional study. BMC Nutrition, 1-10. https://doi.org/10.1186/s40795-016-0064-8

Mandal, S. (2016). PHYTOCHEMICAL ANALYSIS OF GROUNDNUT ( Arachis hypogea L) Swapan Mandal. International Journal of Experimental Research and Review, 6, 35-38.

Maseta, E., Mosha, T. C., Laswai, H., \& Nyaruhucha, C. N. (2016). Nutritional Quality, Mycotoxins and Antinutritional Factors in Quality Protein Maize-Based Supplementary Foods for Children in Tanzania. International Journal of Sciences, 5(7), 38-41. https://doi.org/10.18483/ijSci.1082

McLean, E., Cogswell, M., Egli, I., Wojdyla, D., \& de Benoist, B. (2009). Worldwide prevalence of anaemia, WHO Vitamin and Mineral Nutrition Information System, 1993-2005. Public Health Nutrition, 12(04), 1-11. https://doi.org/10.1017/S1368980008002401

Michaelsen, K. F. (2015). Child growth. World Review of Nutrition and Dietetics, 113, 1-5. https://doi.org/10.1159/000360310

Michaelsen, K. F., \& Greer, F. R. (2014). Protein needs early in life and long-term health 1-4. American Journal of Clinical Nutrition, 99, 718-723. https://doi.org/10.3945/ajen.113.072603.1

Ministry of Health, Community Development, Gender, Elderly and Children (MoHCDGEC) [Tanzania Mainland]. Ministry of Health (MoH) [Zanzibar], National Bureau of Statistic (NBS), Office of the chief Government Statistician (OCGS), and ICF. 2016. Tanzania Demographic and Health Survey and Malaria Indicator Survey (TDHS-MIS) 2015-16. Dar es Salaam, Tanzania, and Rockville, Maryland, USA: MoHCDGEC, MoH, NBS, OCGS, and ICF.

Muthayya, S., Rah, J. H., Sugimoto, J. D., Roos, F. F., Kraemer, K., \& Black, R. E. (2013). The Global Hidden Hunger Indices and Maps: An Advocacy Tool for Action. PLoS ONE, 8(6), 1-12. https://doi.org/10.1371/journal.pone.0067860

National bureau of Statistics (NBS). (2011). Tanzania Demographic and Health Survey 2010. Tanzania Demographic and Health Survey. https://doi.org/zania Demographic and Health Survey 2004-05. Dar es Salaam, Tanzania: National Bureau of Statistics and ORC Macro 
Norhaizan, M. ., \& Norfaizadatul, A. A. (2009). Determination of Phytate, Iron , Zinc , Calcium Contents and Their Molar Ratios in Commonly Consumed Raw and Prepared Food in Malaysia. Mal J Nutr, 15(2), 213-222.

Oghbaei, M., Prakash, J., \& Yildiz, F. (2016). Effect of primary processing of cereals and legumes on its nutritional quality: A comprehensive review. Cogent Food \& Agriculture, 2(1), 1136015.

https://doi.org/10.1080/23311932.2015.1136015

Okomo, P., Egali, I., Bohwere, P., Cercamondi, I., Zeder, C., Njage, P., \& Owino, V. (2016). Estimated Iron and Zinc Bioavailability in Soybean-Maize-Sorghum Ready to Use Foods: Effect of Soy Protein Concentrate and Added Phytase. Journal of Food Processing \& Technology, 07(02), 1-5. https://doi.org/10.4172/2157-7110.1000556

Onoja, U. S., Akubor, P. I., Gernar, D. I., \& Chinmma, C. E. (2014). Evaluation of Complementary Food Formulated from Local Staples and Fortified with Calcium, Iron and Zinc. Journal of Nutrition \& Food Sciences, 4(6), 1-6. https://doi.org/10.4172/2155-9600.1000326

Onomi, S., Okazaki, Y., \& Katayama, T. (2004). Effect of dietary level of phytic acid on hepatic and serum lipid status in rats fed a high-sucrose diet. Bioscience, Biotechnology, and Biochemistry, 66(6), 1379-1381.

Platel, K., \& Srinivasan, K. (2015). Bioavailability of Micronutrients from Plant Foods: An Update. Critical Reviews in Food Science and Nutrition, 00-00. https://doi.org/10.1080/10408398.2013.781011

Rao, A., \& Parikh, A. (2015). Original article prevalence of anemia in school age children. J Adv Med Dent Scie Res, 3(6), 32-35.

Rohner, F., Northrop-Clewes, C., Tschannen, A. B., Bosso, P. E., Kouassi-Gohou, V., Erhardt, J. G., ... Mascie-Taylor, C. N. (2013). Prevalence and public health relevance of micronutrient deficiencies and undernutrition in pre-school children and women of reproductive age in Côte d'Ivoire, West Africa. Public Health Nutrition, 17(9), 1-13. https://doi.org/10.1017/S136898001300222X

Roohani, N., Hurrell, R., Kelishadi, R., \& Schulin, R. (2013). Zinc and its importance for human health: An integrative review. J Res Med Sci, 18(2), 144-157.

Shiriki, D., Igyor, M. A., \& Gernah, D. I. (2015). Nutritional Evaluation of Complementary Food Formulations from Maize , Soybean and Peanut Fortified with Moringa oleifera Leaf Powder. Food and Nutrition Sciences, 6(April), 494-500. https://doi.org/10.4236/fns.2015.65051

Skau, J. K. H., Bunthang, T., Chamnan, C., Wieringa, F. T., Dijkhuizen, M. a., Roos, N., \& Ferguson, E. L. (2014). The use of linear programming to determine whether a formulated complementary food product can ensure adequate nutrients for 6- to 11-month-old Cambodian infants. American Journal of Clinical Nutrition, 99(1), 130-138. https://doi.org/10.3945/ajcn.113.073700

Steiber, A., Hegazi, R., Herrera, M., Landy Zamor, M., Chimanya, K., Pekcan, A. G., ... Ojwang, A. A. (2015). Spotlight on Global Malnutrition: A Continuing Challenge in the 21st Century. Journal of the Academy of Nutrition and Dietetics, 115(8), 1335-1341. https://doi.org/10.1016/j.jand.2015.05.015

Steve, I. O., \& Babatunde, O. I. (2013). Chemical Compositions and Nutritional Properties of Popcorn-Based Complementary Foods Supplemented With Moringa oleifera Leaves Flour. Journal of Food Research, 2(6), 117-132. https://doi.org/10.5539/jfr.v2n6p117

Sudfeld, C. R., Charles McCoy, D., Danaei, G., Fink, G., Ezzati, M., Andrews, K. G., \& Fawzi, W. W. (2015). Linear Growth and Child Development in Low- and Middle-Income Countries: A Meta-Analysis. Pediatrics, 135(5), e1266-e1275. https://doi.org/10.1542/peds.2014-3111

Udensi, E. A., Odom, T. C., \& Ihemanma, O. J. N. R. O. E. C. A. (2012). Production and evaluation of the nutritional quality of weaning food formulation from roasted millet and Mucuna cochinchinesis. Sky Journal of Food Science, 1(1), 1-5.

Unicef. (2013). Improving child nutrition. The achievable imperative for global progress. https://doi.org/978-92-806-4686-3

United States Department of Agriculture. (2009). Nutritional Needs of Infants Dietary Reference Intakes ( DRIs ). In Infant Nutrition and Feeding (pp. 11-40). Retrieved from http://www.nal.usda.gov/wicworks/Topics/FG/Chapter1_NutritionalNeeds.pdf

Warthon-Medina, M., Moran, V. H., Stammers, A.-L., Dillon, S., Qualter, P., Nissensohn, M., ... Lowe, N. M. (2015). Zinc intake, status and indices of cognitive function in adults and children: a systematic review and 
meta-analysis. European Journal of Clinical Nutrition, 69(6), 649-661. https://doi.org/10.1038/ejcn.2015.60

WHO. (2009). Infant and young child feeding. In Infant and young child feeding, 155, 1-79. https://doi.org/10.1111/j.1740-8709.2009.00234.x

WHO. (2011). Haemoglobin concentrations for the diagnosis of anaemia and assessment of severity. Geneva, Switzerland: World Health Organization. https://doi.org/2011

Wieser, S., Plessow, R., Eichler, K., Malek, O., Capanzana, M. V, Agdeppa, I., \& Bruegger, U. (2013). Burden of micronutrient deficiencies by socio-economic strata in children aged 6 months to 5 years in the Philippines. BMC Public Health, 13, 1-15. https://doi.org/10.1186/1471-2458-13-1167

Wong, A. Y. S., Chan, E. W., Chui, C. S. L., Sutcliffe, A. G., \& Wong, I. C. K. (2014). The phenomenon of micronutrient deficiency among children in China: a systematic review of the literature. Public Health Nutrition, 17(11), 2605-18. https://doi.org/10.1017/S1368980013002978

\section{Copyrights}

Copyright for this article is retained by the author(s), with first publication rights granted to the journal.

This is an open-access article distributed under the terms and conditions of the Creative Commons Attribution license (http://creativecommons.org/licenses/by/4.0/). 